Rev. Biol. Trop., 48(2/3): 443-447, 2000

www.ucr.ac.cr www.ots.ac.cr www.ots.duke.edu

\title{
A new species of Acestrocephalus (Characiformes: Characidae) from Venezuela
}

\author{
Carlos A. Lasso ${ }^{1}$ and Donald Taphorn ${ }^{2}$ \\ 1 Museo de Historia Natural La Salle, Apartado 1930, Caracas 1010-A, Venezuela. Fax: 582 7937493; e-mail: \\ lassoc@usa.net \\ 2 Universidad Experimental de los Llanos Ezequiel Zamora, Guanare, Portuguesa 3310, Venezuela. e-mail: \\ taphorn@cantv.net
}

Received 11-VIII-1999. Corrected 11-II-2000. Accepted 24-II-2000.

\begin{abstract}
A new species of Acestrocephalus is described from 60 specimens collected in the Río Orinoco and Río Negro drainages, Venezuela. This species is distinguished from all other Acestrocephalus by the combination of the following characters: anal rays, 29-36; 63-71 perforated scales on the lateral line; 10-12 scales above and $9-12$ below the lateral line; 39-52 teeth on the maxillary; $9-12$ premaxillary teeth; $8-12$ teeth in the inner row on the dentary; 5-7 gill rakers on the lower part of the first gill arch; humeral, peduncular and caudal blotch absent.
\end{abstract}

Key words: Characiformes, Characidae, Acestrocephalus, new species, Río Orinoco, Río Negro, Venezuela.

The genus Acestrocephalus Eigenmann, 1919 is represented by three species: A. anomalus (Steindachner, 1879) (restricted to the Magdalena Basin), A. sardina (Fowler, 1913) and A. boehlkei (Menezes, 1977) (both distributed in the Amazon Basin). Some authors (e. g. Géry, 1977) consider Acestrocephalus as a subgenus of the genus Cynopotamus Valenciennes, 1849. Menezes (1976) established the subfamily Cynopotaminae and elevated Acestrocephalus to generic status.

\section{MATERIAL AND METHODS}

Counts and measurements follow Menezes $(1976,1977)$. Procedures for preparing cleared and stained material follow Taylor (1967). Museum abbreviations: MCNG, Museo de
Ciencias Naturales de la UNELLEZ en Guanare, Guanare, Estado Portuguesa; MHNLS, Museo de Historia Natural La Salle, Caracas, Venezuela. Morphometric and meristic data for Acestrocephalus anomalus, A. boehlkei and A. sardina are from Menezes $(1976,1977)$. Data for the Apure drainage population identified as A. afboehlkei are from Taphorn (1992) and were reconfirmed using specimens from MCNG and MHNLS.

Acestrocephalus ginesi, sp. nov.

(Figs. 1-2, Table 1-2)

Material examined - Holotype. MCNG 3468i (74.4 mm SL). Venezuela, Apure State, Río Cinaruco, playa en frente de Laguna Larga, Distrito Muñoz (06 $\left.33^{\prime} 45^{\prime \prime} \mathrm{N}-67^{\circ} 24^{\prime} \mathrm{W}\right)$. Collected 4 April 1997, D. Jepsen and D. 
Rodriguez. Paratypes. MCNG 37820, 14 ex. (51.4 - $79.6 \mathrm{~mm} \mathrm{SL}$ ). Same data as holotype. MCNG 17956, 2 ex. (73.9 - 76.3 mm SL). Venezuela, Apure State, Río Cinaruco, cerca de la desembocadura con el Río Orinoco (aprox. $06^{\circ} 41^{\prime} \mathrm{N}-67^{\circ} 06^{\prime} \mathrm{W}$ ). Collected 31 December 1986, D.C. Taphorn. MCNG $37821 \quad$ (55 mm SL, cleared and stained). Same data as MCNG 17956. MHNLS 12762 (52,3 mm SL). Same data as MCNG 17956. MCNG 18029, 4 ex. (51.4 - $53.8 \mathrm{~mm} \mathrm{SL}$ ). Venezuela, Apure State, Río Cinaruco, Hacienda El Cocal, Paso de la Chalana $\left(6^{\circ} 35^{\prime} 30^{\prime \prime} \mathrm{N}-67^{\circ} 14^{\prime \prime} \mathrm{W}\right)$. Collected 30 December 1986, D. C. Taphorn, B. Stergios and P. Stergios. MCNG 23305, 5 ex. (76.9 - 121.8 $\mathrm{mm}$ SL). Venezuela, Amazonas State, Río Guainía en Maroa, Departamento de Casiquiare $\left(2^{\circ} 44^{\prime} 0^{\prime \prime} \mathrm{N}-67^{\circ} 34^{\prime} \mathrm{W}\right)$. Collected 9 August 1989, L. Hoigne and D. C. Taphorn. MCNG 37822, 6 ex. (85.4 - 109.4 mm SL). Venezuela, Amazonas State, Río Sipapo a $150 \mathrm{~m}$ arriba del Salto Remo, Departamento Atures ( $4^{\circ} 34^{\prime} 28^{\prime \prime}$ N - $67^{\circ} 17^{\prime}$ W). Collected 29 May 1989, L. Nico and E. Guayamare. MCNG 12098, 5 ex. (66.5 -
$100.7 \mathrm{~mm} \mathrm{SL}$ ). Venezuela, Amazonas State, Río Negro, San Carlos de Río Negro, Departamento de Río Negro ( $1^{\circ} 55^{\prime} 0^{\prime \prime} \mathrm{N}-67^{\circ} 04^{\prime} \mathrm{W}$ ). Collected 12 April 1985, L. Nico. MCNG 26048, 3 ex. (59.9 - 73.7 mm SL). Venezuela, Amazonas State, Río Siapa a $176 \mathrm{~km}$ aguas arriba de la desembocadura con el Caño Casiquiare, Departamento de Casiquiare $\left(1^{\circ} 25^{\prime}\right.$ 0" N - 65 41' W). Collected 17 April 1991, A. Barbarino \& D. Morillo. MHNLS 12807, 3 ex. (73.4 - $83.7 \mathrm{~mm} \mathrm{SL}$ ). Same data as MCNG 26048. MCNG 37823, 5 ex. (65.7 - $90.3 \mathrm{~mm}$ SL). Venezuela, Amazonas State, Río Orinoco, playas Isla Trucoapure. Collected 13 February 1991, L. Nico \& J. Castillo. MCNG 37825, 5 ex. (57.3 - $94.2 \mathrm{~mm} \mathrm{SL}$ ). Venezuela, Amazonas State, Río Orinoco, debajo de la Comunidad Cariche ( $\left.3^{\circ} 2^{\prime} 00^{\prime \prime} \mathrm{N}-66^{\circ} 25^{\prime} \mathrm{W}\right)$. Collected 20 January 1991, L. Nico \& G. Aragua. MCNG 37824, 5 ex. (61.4 - $88.2 \mathrm{~mm} \mathrm{SL).} \mathrm{Venezuela,}$ Amazonas State, Río Orinoco, Isla Tigre, entre Macuruco y Guachapana, Departamento Atabapo ( $3^{\circ} 55^{\prime} 00^{\prime \prime} \mathrm{N}-67^{\circ} 0^{\prime} \mathrm{W}$ ). Collected 20 February 1991, L. Nico \& F. Morillo.

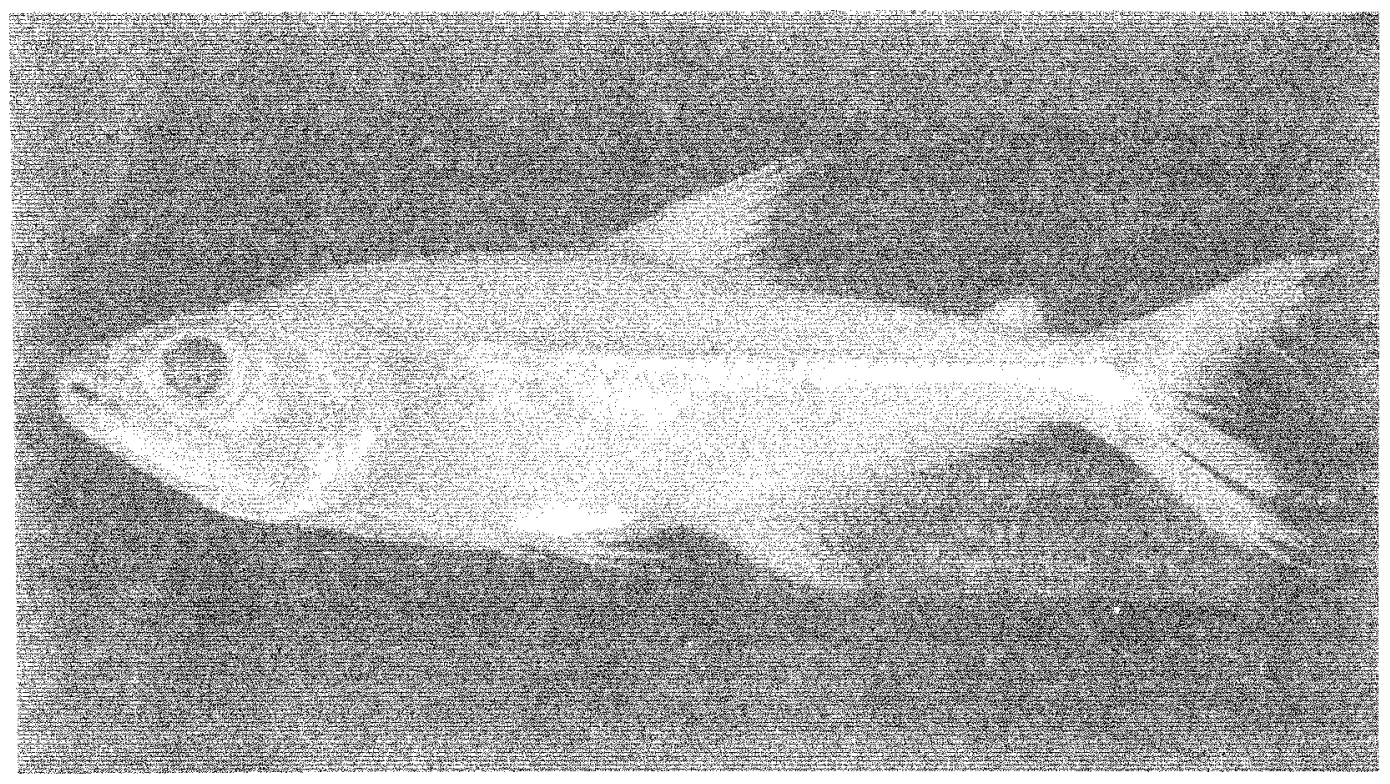

Fig. 1. Acestrocephalus ginesi, holotype, $74.4 \mathrm{~mm}$ SL, MCNG 34681. 
Etymology. This species is named in honor of Hermano Ginés president of the La Salle Natural Science Foundation, in recognition of his outstanding contribution to the study and protection of neotropical ecosystems.

Diagnosis. Acestrocephalus ginesi differs from all other Acestrocephalus species by the combination of the following characters: anal fin, iv $+25-32$ (iii +27 in one specimen and $v+25$ in other specimen); $63-71$ perforated scales on lateral line; $10-12$ scales above, $9-12$ below lateral line; 39 - 52 teeth on maxillary; $9-12$ premaxillary teeth; $8-12$ teeth in inner dentary row; $5-7$ gill rakers on lower part of first gill arch; humeral blotch absent; dark blotch on caudal peduncle fin weak to absent; vestiges of small dark spot at origin of dorsal fin; tip of lower jaw with scattered dark melanophores, especially in small specimens ( $52 \mathrm{~mm}$ SL or less).

Description. Morphometric and meristic data of holotype and 45 paratypes are given in Tables 1 and 2. Body relatively small (SL 51.4 $121.8 \mathrm{~mm}$ ); ven $\mathrm{ral}$ outline slightly more curved than dorsal. Snout rather short, less than orbital diameter. Maxilla with 39 - 52 teeth, its posterior border convex. Premaxilla with 9 - 12 teeth, including anteriormost and posterior canines of external tooth row. First tooth in outer dentary row a large canine followed by two or three conical teeth (first and third smaller and second similar to anteriormost canine) followed by row of $28-44$ small conical teeth. Inner row on dentary with $8-12$ teeth. Gill rakers on inferior lobe of first arch: $6+0$ rudiment (35), $6+2$ rudiments (2), $7+0$ rudiments (2) and $7+1$ rudiment (6).

Scales relatively large. Lateral line scales: 63 (1), 64 (1), 65 (1), 66 (2), 67 (13), 68 (6), 69 (7), 70 (11) and 71 (4). Scales above lateral line: 10 (7), 11 (32) and 12 (7). Scales below lateral line: 10 (32), 11 (12) and 12 (2). Anal fin base covered by a row of scales that extends to middle of fin.

Dorsal fin: ii +9 (45) and iii +10 (1); first branched ray four times longer than last and first simple ray contained about two times in second unbranched ray. Interradial membranes with sheath of skin that occupies most of interradial space, sheath decreasing in length after third or fourth ray, and becoming unnoticeable on second to last ray. Anal fin: iii +27 (1), iv +25 (1), iv + 27 (1), iv + 28 (3), iv + 29 (10), iv + 30 (9), iv + 31 (12), iv +32 (8) and $v+25$ (1); falcate anteriorly (the 4th, 5th and 6th rays are longer than the rest) with sheath of skin covering most of interradial space of first anal rays; origin of anal situated below base of last dorsal ray. Pectoral fin: $i+13$ (24) and $i+14$ (22); longer than pelvics, longest rays reaching origin of pelvics. Pelvic fin: $\mathrm{i}+7$ (46); tips of pelvics reaching or passing anus. Principal caudal rays: $i$ $+17+i$ (46); caudal fin with inferior lobe a bit larger than upper.

TABLE 1

Morphometric data for the holotype and 45 paratypes of Acestrocephalus ginesi

\begin{tabular}{lcccc} 
Percents of standard length & Range & Mean & SD & Holotype \\
Head length & $29.3-32.8$ & 30.7 & 2.33 & 23.8 \\
Trunk length & $68.4-71.9$ & 68.4 & 1.12 & 51 \\
Body depth & $23.5-32.9$ & 27.1 & 1.70 & 19.6 \\
Orbital diameter & $9.7-13$ & 11.1 & 0.65 & 9 \\
Snout length & $6.1-8.3$ & 7.3 & 0.50 & 5.7 \\
Preanal distance & $50.3-62.6$ & 59.8 & 1.45 & 45.2 \\
Interorbital width & $5.6-9$ & 7 & 0.75 & 5.3 \\
Caudal peduncle depth & $6.8-8.4$ & 7.6 & 0.30 & 5.4 \\
Predorsal distance & $49.3-54.8$ & 51.2 & 0.85 & 38 \\
Percents of head length & & & & \\
& & & & \\
Body depth & $75.2-101.3$ & 91.2 & 4.90 & 82.4 \\
Orbital diameter & $30.6-41.4$ & 37 & 2.60 & 37.8 \\
Snout length & $20-26.7$ & 23.3 & 1.70 & 23.9 \\
Interorbital width & $17.8-28.6$ & 22.6 & 2.41 & 22.3 \\
Caudal peduncle depth & $21.7-26.3$ & 24.3 & 1.10 & 22.7 \\
* holotype (74.4 mm SL), paratype (51.4 -121.8 mm SL) & \multirow{2}{*}{$* *$ SD:standard deviation }
\end{tabular}


TABLE 2

Meristic data for the holotype and 45 paratypes of Acestrocephalus ginesi

$\begin{array}{lc}\text { Meristics } & \text { Range } \\ & \\ \text { Dorsal fin } & \text { ii }+9-\mathrm{iii}+10 \\ \text { Anal fin } & \text { iii }-\mathrm{v}+25-32 \\ \text { Pectoral fin } & 14-15 \\ \text { Ventral fin } & \mathrm{i}+7 \\ \text { Principal caudal rays } & \mathrm{i}+17+\mathrm{i} \\ \text { Lateral line scales } & 63-71 \\ \text { Scales above lateral line } & 10-12 \\ \text { Scales below lateral line } & 9-12 \\ \text { Gill rakers } & 5-7 \\ \text { Premaxillary teeth } & 9-12 \\ \text { Maxillary teeth } & 39-52 \\ \text { Posterior dentary teeth } & 28-44 \\ \text { Inner teeth on the dentary } & 8-12\end{array}$

General body color in $70 \%$ ethanol is pallid yellow. A series of very diffuse melanophores extends from upper angle of opercle to base of caudal fin. Humeral spot absent. Just a few melanophores on inferior part or tip of mandible, more evident in specimens less than $57 \mathrm{~mm}$ SL. Fins hyaline.

Distribution. This species is known only from southern Apure in the Cinaruco river and from the upper Orinoco and Negro drainages in Amazonas state (Fig. 2).

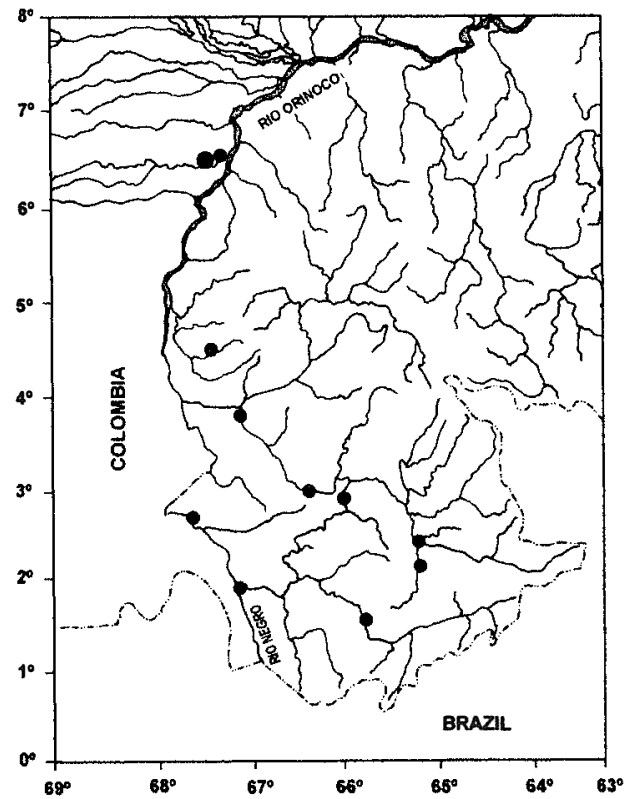

Fig. 2. Distribution of Acestrocephalus ginesi new species in southern Venezuela. Largest dot indicates type locality in the Cinaruco river. Dots may represent more than one collection.

$\begin{array}{cc}\text { Mode } & \text { Holotype } \\ \text { ii }+9 & \text { ii }+9 \\ \text { iv, } 31 & \text { iv, } 29 \\ 14 & \text { i, } 14 \\ \mathrm{i}+7 & \mathrm{i}+7 \\ \mathrm{i}+17+\mathrm{i} & \mathrm{i}+17+\mathrm{i} \\ 67 & 67 \\ 11 & 11 \\ 10 & 12 \\ 6 & 6 \\ 11 & 11 \\ 44 & 46 \\ 32 & 33 \\ 9 & 9\end{array}$

\section{DISCUSSION}

Five diagnostic characters permit the separation of $A$. ginesi from the other species: 1) the lower number of total anal rays (29- 36 vs. 37 - 41 in A. boehlkei and 37 - 39 in A. anomalus), only $A$. sardina an Amazonian headwater species has 33 - 37 anal rays; 2) a lower number of pored lateral line scales (6371 vs. 71-78); 3)f ewer transverse scales above the lateral line (10-12 vs. 12-14); 4) greater number of maxillary teeth (39-52 vs. 32-44); 5) the absence of a spot on the caudal peduncle and the base of the caudal fin. In addition, $A$. ginesi differs by the absence of a humeral spot. In A. boehlkei and A. sardina this spot is quite evident. Acestrocephalus anomalus may present only vestiges of the humeral spot. $A$. ginesi shares with $A$. boehlkei a small spot at the tip of the lower jaw, a character that is more evident in smaller specimens. This spot is absent in the other two species. This new species also has vestiges of a spot at the origin of the dorsal fin, a character that it shares with the other three. The number of transverse scales below the lateral line (9-12) separates in part $A$. ginesi from A. boehlkei and A. sardina (12-13), but overlaps with $A$. anomalus (9-11). The range of the number of premaxillary teeth coincides with $A$. boehlkei (9-12), but differs from A. sardina and A. anomalus (7-11). Acestrocephalus ginesi has a very large eye, its orbital diameter $30.6-41.1 \%$ (mean $=37 \%$ ) of 
the head length, (25.0-34.8 in A. boehlkei as calculated from Table 2 in Menezes 1977).

The three described species of the genus Acestrocephalus have either an Amazonian distribution (A. sardina and A. boehlkei) or Magdalenan (A. anomalus) distribution. Acestrocephalus ginesi represents the second report of this genus from the Orinoco Basin. Taphorn (1992) indicated the presence of a species tentatively identified as Acestrocephalus cf boehlkei Menezes 1977 from the Apure River system. That species differs from A. ginesi in having a greater number of branched anal-fin rays (35-38 vs. 29-36) and a greater number of scales on the lateral line (73-76 vs. 63-71). The presence of humeral and caudal spots also distinguishes the Apure form from A. ginesi. The report of A. boehlkei from the Ventuari River (upper Orinoco) of Taphorn (1992) requires confirmation.

\section{ACKNOWLEDGEMENTS}

We thank Oscar Lasso-Alcalá for taking the photograph; UNELLEZ BioCentro and Fundación La Salle logistic for support and museum processing; MAC-SARPA for issuing the scientific permits. Antonio MachadoAllison and Francisco Provenzano revised the manuscript.

\section{RESUMEN}

Se describe una nueva especie, Acestrocephalus ginesi, con base a 60 ejemplares recolectados en las cuencas del Río Orinoco y Río Negro, Venezuela. Esta especie difiere de otros miembros del género por la siguiente combinación de caracteres: aleta anal, 29-36 radios; 63-71 escamas con poro en la línea lateral; escamas transversales 10-12 / 9-12; 39-52 dientes en el maxilar; 912 dientes en el premaxilar; 8-12 dientes en la fila interna del dentario; 5-7 branquispinas en la parte inferior del primer arco branquial; mancha humeral, peduncular y caudal, ausentes.

\section{REFERENCES}

Géry, J. 1977. Characoids of the World. T. F. H. Neptune City, New Jersey. 672 p.

Menezes, N. 1976. On Cynopotaminae, a new subfamily of Characidae (Osteichthyes, Ostariophysi, Characoidei). Arq. Zool. 28: 1-91.

Menezes, N. 1977. Acestrocephalus boehlkei, a new and disjunct Cynopotamine from Ecuadorean and Peruvian Amazon (Osteichthyes, Ostariophysi, Characidae). Pap. Avul. Zool., S. Paulo 30: 185196.

Taphorn, D. 1992. The Characiform Fishes of the Apure River Drainage, Venezuela. Biollania 4: 1-537.

Taylor, W. R. 1967. An enzyme method of clearing and staining small vertebrates. Proc. U. S. Nat. Mus. 122: 1-17. 